such as system differentiation, cost efficiency, and diversification of funding sources are less frequently addressed. A few countries—such as South Africa, Tanzania, and Uganda-have enacted substantial changes to their legal frameworks, equaling or exceeding good practices worldwide. In other countries-such as Botswana, Cameroon, Ethiopia and Malireforms have been noteworthy but less bold.

Francophone countries in particular have lagged the rest of the continent in both the number and ambition of their higher education reform efforts. Although notable differences characterize the legal systems and university traditions of Frenchand English-speaking countries, recent changes to the legal frameworks for Anglophone higher education should provide heuristic examples for those Francophone systems interested in renewal and modernization. To facilitate comparative learning and further research on the legal frameworks for subSaharan African higher education systems, universities in this region might post current copies of relevant higher education acts, university statutes, and associated decrees or regulations on their Web sites.

\section{Mongolia's Challenge: Becoming Asian in Higher Education}

\section{Gerard Postiglione}

Gerard Postiglione, is professor and head of the Division of Policy, Administration, and Social Science, Faculty of Education, University of Hong Kong.E-mail: gerry@hku.hk.

$\mathrm{D}$ espite the global economic crisis, the Republic of Mongolia is determined to move ahead in restructuring its higher education system. Not generally known, its education indicators rival those of its closest neighbors-China, South Korea, and Japan. It has a literate population, a popularized school system, and a higher education enrollment rate that is approaching 80 percent. Since I990, when it moved from a planned to a market economy, the private higher education sector has grown to encompass a third of all enrollments. Most colleges and universities are in the capital city where 40 percent of the national population resides. The rest of the population, also literate and schooled, adheres to a nomadic lifestyle. English has replaced Russian as the declared second language of this land of 2.8 million, the largest landlocked country in the world. Historical circumstance made Mongolia the most
Europeanized state in East Asia. However, its people retained the Asian value of acquiring as much education as possible.

\section{Untying Knotty Problems}

Mongolia ranks 7 th internationally in the percent of the gross domestic product (GDP) (9.0\%) for education, and its education law guarantees that at least 20 percent of the government budget is spent on education. Yet, higher education receives only I2 percent of that amount. This made sense for a developing country in transition. However, the time is ripe for a rethink of the higher education system, including its funding structure. State universities obtain government funds for heating and lighting, but little else. One university leader pointed out that 80 percent of academic staff salaries come from student fees. A national fund for higher education provides coverage to one child from each civil servant family, and support is also offered for outstanding students from poor families. However, there is also a view that higher education is a source of poverty because 67 percent of the personal loans taken by countryside cattle rancher families are spent on the higher education of their children.

Mongolia ranks 7 th internationally in the percent of the gross domestic product (9.0\%) for education, and its education law guarantees that at least 20 percent of the government budget is spent on education.

With such literacy, school attendance, and higher education enrollment rates, as well as a sustained Asian value toward education, the Republic of Mongolia would seem to be in a good position to move ahead with a higher education restructuring that brings the standard of teaching and research to internationally recognized levels. Nevertheless, several daunting challenges remain.

\section{URGent Challenges}

Government spending on higher education is severely limited in comparison to other regional players. For example, Malaysia and Hong Kong tower over most Asian countries with respect to per student expenditure as a percentage of GDP. Mongolia's transition to a market-oriented system included introducing fees for higher education. However, unlike Japan, Korea, and China, Mongolia's government could not make the same investment in its top universities. Investment does matter. Hong Kong spends about 30 percent of the education budget on higher education and has the highest concentration of toprated universities in one city than elsewhere in Asia. While some Asian governments allocate a smaller slice of the pie to higher education, quality is not going to be achievable with a I2 percent slice of the education budget for higher education. 
The quality of private higher education has yet to surpass that of the public institutions. Despite their short history, private institutions are catching up and some offer programs competitive with those at public institutions. One view is that state institutions receive such a small portion of funding that they actually operate with state titles but in private mode. However, the private sector declares virtually no support is provided by government and that the current balance of enrollments should be reversed-that is, one third of enrollments should be in state institutions with the private institutions enrolling the rest. In Korea, Japan, Taiwan, the Philippines, and Indonesia private universities enroll the majority of students-in some cases upwards of 80 percent. Mongolia's private institutions enroll 34 percent of all students and believe that a level playing field is lacking.

\section{Therefore, Mongolia's research universities will remain hard pressed without a larger national RQD budget.}

With far too many ( $\mathrm{I}_{6} 2$ ) institutions, the average number at each one is about 900 students-no way to attain economies of scale. Consolidation has been used to address this problem elsewhere. The average number of students in Chinese institutions was 3,II2 in I990, up from I,919 in I990, when about 80 percent of higher education institutions had less than 4,000 students and 60 percent had less than 3,000 students. By 2000, 6I2 colleges and universities were consolidated into 250 , and several universities now have over 50,000 students. Other countries are dealing with similar problems, especially at the outset of privatization, when an overabundance of small colleges spring up with little to offer in the way of quality instruction. After the initial phase of privatization, a system is needed for quality assurance, which often ends in the closure and consolidation of many institutions.

Mongolia's premier universities have obtained too few faculty members for the number of students served, about a $1: 23$ teacher-student ratio. At top universities elsewhere, the ratio is lower. It is I:IO.5 at the University of Pennsylvania and I:II.5 at New York University. In the engineering faculty of the National University of Singapore, it is I:I3. In the recent QS World University rankings of top universities in the world, studentfaculty ratio counted for 20 percent of the ranking. While student-faculty ratio is not automatically indicative of quality teaching and research, it is relevant enough for Mongolia to consider recruitment of outstanding academic staff.

Mongolia aspires, as do its neighbors in Northeast Asia (Japan, South Korea, and China) to have internationally recognized research universities. The intention to establish a highly recognized research university needs to be matched by a national budget that does not skimp on funds for research and development. Some observers continue to argue that making a direct association with research productivity is risky. The R\&D budget for Hong Kong is only 0.7 percent of GDP but has very high per capita rates of research publications. Regardless, Mongolia's R\&D budget of 0.28 percent of GDP places it 7oth in the world. Hong Kong ranks 50th. Moreover, Mongolia has a military and natural resources, which Hong Kong lacks. Therefore, Mongolia's research universities will remain hard pressed without a larger national R\&D budget.

The academic profession must find better ways to retain top scholars. Meager salaries are an obstacle to improving quality. It is not unusual for faculty to leave their university to enter business where they can earn a higher wage. At present, parttime staff who need to work elsewhere to supplement their income account for I8 percent in public and 44 percent in private institutions. Winning the best academic staff should be a priority, but the state of the economy greatly inhibits the ability of colleges and universities to attract and retain the talent needed to significantly improve the quality and competitiveness of higher education.

\section{A Brighter Vision or More of the Same?}

While many people agree that the discovery of one of the world's largest mineral deposits (coal, copper, and uranium) means a promising economic future awaits Mongolia, the economy is currently too weak to support the large number of university graduates, and many are seeking employment elsewhere. Unless the above challenges facing higher education are urgently addressed with the political will necessary to overcome entrenched self-interests, Mongolia may find itself illprepared to take advantage of the opportunities on its horizon.

\section{Celebrating 200 Years of Humboldt University}

\section{Sebastian Litta}

Sebastian Litta studied at Freie Universität Berlin and is now a McCloy Scholar at the Harvard Kennedy School. E-mail: sebastian_litta@hks1o.harvard.edu.

$\mathrm{O}$ October I5, I8Io a new university was founded in Berlin. With only 256 students and 53 professors, this university had modest beginnings, but it would eventually shape the entire German as well as the international higher education landscape. The Universität zu Berlin, later renamed Humboldt Universität, revolutionized the concept of a university. Harvard 